5. Гринченко А.С., Алферов А.И. Прогнозирование надежности элементов машин при случайном пуассоновском потоке экстремальных нагружений Науковий журнал «Технічний сервіс агропромислового, лісового та транспортного комплексів». 2017. № 7 С. 141-148.

DOI https://doi.org/10.30525/978-9934-26-046-9-20

\title{
ТЕХНІЧНЕ ДІАГНОСТУВАННЯ В СИСТЕМІ ТЕХНІЧНОЇ ЕКСПЛУАТАЦІЇ АВТОМОБІЛІВ
}

\author{
Блезнюк О. В. \\ кандидат технічних наук, дочент \\ Харківський начіональний технічний університет \\ сільського господарства імені Петра Василенка \\ Іванов B. I. \\ кандидат технічних наук, доцент \\ Харківський начіональний технічний університет \\ сільського господарства імені Петра Василенка \\ м. Харків, Украӥна
}

Існує нагальна проблема підвищення рівня технічної експлуатації автомобілів (TEA), що корелюється із їх технічним станом і надійністю. Одним з найважливіших показників, що впливають на якість системи TEA, є оперативність і якість виконуваних робіт, які визначаються кваліфікацією виконавців послуг та наявністю повної науковотехнічної документації [1]. Аналіз причинно-наслідкової схеми якості виконання робіт (рис. 1) показав, що дослідження першопричини дефекту необхідно вести за категорією «порушення технології працівниками».

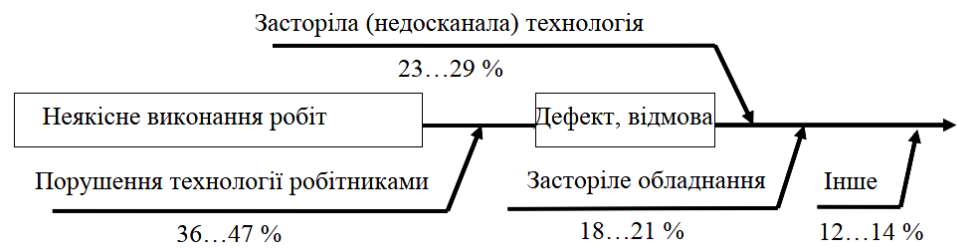

Рисунок 1. Причинно-наслідкова схема якості виконання робіт 
Однією з основних умов організації та проведення робіт з технічного обслуговування (ТО) і діагностування (ТД) $є$ наявність у кожного фахівця і виконавця повного комплекту науково-технічної документації та довідкового матеріалу з усіх аспектів операцій обслуговування і засобів автоматизованих обчислень прогнозних і оціночних показників за результатами діагностування.

При підвищенні надійності автомобілів перевага віддається більш досконалій схемі управління процесами ТО, яка передбачає визначення стану вузлів шляхом інструментального контролю. Наявність в системі ТО елементів ТД дозволяє попередити можливі відмови, скоротити кількість невиправданих ремонтів, більш повно використовувати технічний ресурс автомобіля [2]. Впровадження діагностики дозволяє в 1,3 ...1,5 рази збільшити фактичне міжремонтне напрацювання, зменшити число відмов в $2 . .2,5$ рази, зменшити витрату палива на $5 \ldots 8 \%$ [3]. Найбільш перспективним $є$ автоматизація управління процесом ТО за результатами ТД вузлів і з'єднань, яка вимагає впровадження сучасних інформаційних технологій на всіх рівнях виробництва, починаючи з бортової електроніки автомобіля і закінчуючи інформаційною системою, яка охоплює всі структури АПВ. Дослідження процесу управління технічним станом автомобіля дозволяє визначити роль і необхідність використання інформації для прийняття рішення. У загальному випадку управління технічним станом конкретного автомобіля включає вимірювання параметрів стану іiі складових частин, порівняння встановлених значень 3 допустимими або граничними величинами, визначення залишкового ресурсу складових частин, призначення виду та обсягу обслуговуючих впливів і виконання всіх встановлених робіт (рис. 2).

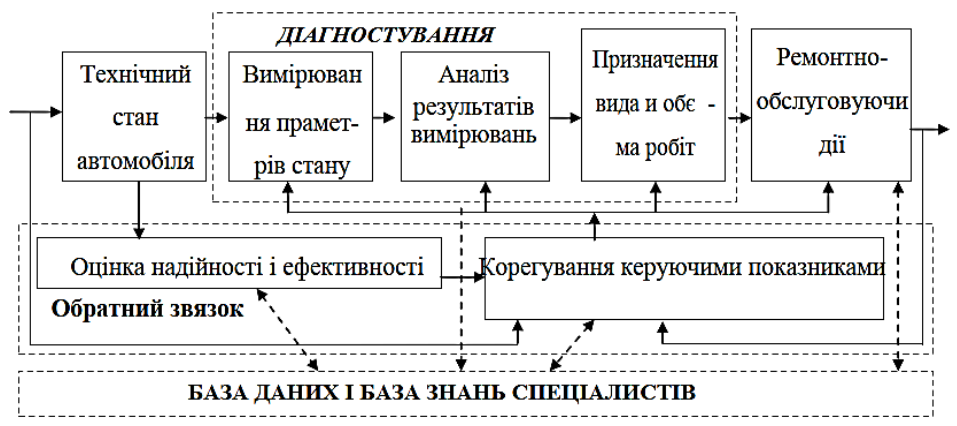

Рисунок 2. Схема управління технічним станом автомобіля 
Сутність застосування системи технічного обслуговування з контролем технічного стану автомобілів полягає у впровадженні в систему TO з напрацювання регламентних видів контролю, які дозволяють регулярно перевіряти фактичний стан автомобілів і своєчасно запобігати виникненню відмов і пошкоджень 3 експлуатаційних причин, забезпечуючи відповідний працездатний стан автомобілів. За допомогою комплексу технічних засобів встановлюється перелік операцій, потреба у виконанні яких визначається технічним станом автомобілів в момент початку ТО, що значно скорочує трудомісткість виконання робіт. Основним видом контролю технічного стану при використанні автомобілів за призначенням є ТД [4], яке проводиться з метою отримання інформації щодо фактичного стану вузлів і агрегатів автомобілів на момент перевірки і дозволяє визначити обсяг робіт з ТО, що забезпечує їх підтримку в справному або працездатному стані.

Обсяг діагностичних операцій для автомобілів в системі АПВ становить близько $30 \%$ від загального обсягу технічного обслуговування, що свідчить, по-перше, про важливість підвищення контролепридатності автомобілів i, по-друге, про необхідність вдосконалення методів і засобів технічного діагностування [5]. Це підтверджується динамікою підвищення трудомісткості діагностичних операцій. Питома трудомісткість діагностування та його частка в загальному обсязі технічного обслуговування також безперервно зростає. Закономірність зростання трудомісткості діагностування вказує також на тенденцію іiі подальшого збільшення. Як процес визначення технічного стану автомобілів технічне діагностування зумовлюе наявність системи діагностування, що представлена на рис 3.

Основними складовими системи технічного діагностування $є$ : об'єкт діагностування, засоби діагностування, персонал, технічна документація. Система технічного діагностування повинна враховувати ряд особливостей, властивих автомобілям як об'єкту діагностування. В основному це зумовлено специфікою автомобілів, що представляють собою складний об'єкт діагностування з багатоелементною структурою і різнорідними фізичними робочими процесами [6]. Крім того, до особливостей автомобіля, як об'єкта діагностування, слід віднести також складність конструкції агрегатів, що обумовлює значні труднощі у виборі параметрів технічного стану. 


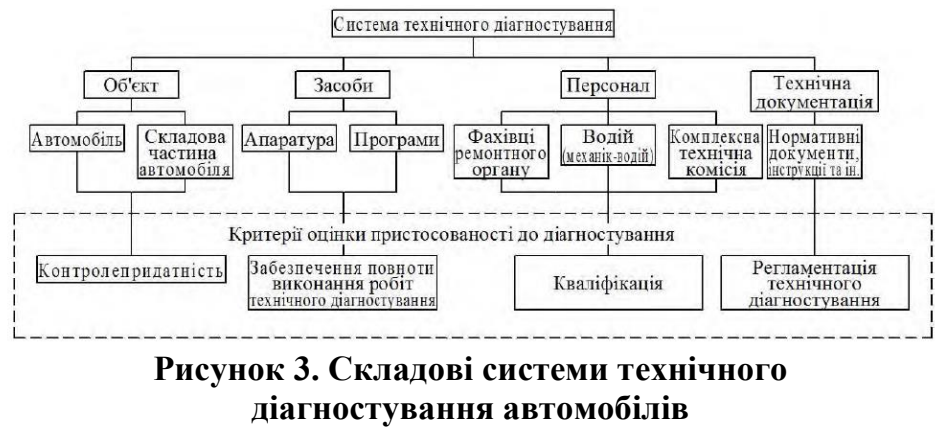

Відповідно до вищевикладеного можна зробити висновок щодо провідної ролі технічного діагностування в системі технічної експлуатації автомобілів, підвищення ефективності якої не можливо без розробки нових методів технічного діагностування.

\section{Література:}

1. Кузнецов Е.С., Болдин Е.С.Техническая эксплуатация автомобилей: учебник для вузов. Москва: Наука, 2001. 535 с.

2. Блезнюк О.В., Іванов В.І. Впровадження програми превентивного ремонту автомобілів на підприємстві. Матеріали Міжнародної науково-практичної конференції «Автомобільний транспорт в аграрному секторі: проектування, дизайн та технологічна експлуатація». Харків: ХНТУСГ, 2020. С. 51-52.

3. Черных Ю.Г., Хмелевой Н.М. Рациональное техническое обслуживание - гарантия высокоэффективного использования техники. Механизация и электрификация сельского хозяйства. 1988. № 5. C. 41-44.

4. ДСТУ 2389-94 Технічне діагностування та контроль технічного стану. Київ: Держстандарт України, 1994. 24 с.

5. Блезнюк О.В. Трощенко В.В. Дослідження питання оцінки системи технічного обслуговування машин на підприємстві. IV Всеукраїнська науково-практична конференція «Перспективи і тенденції розвитку конструкцій та технічного сервісу сільськогосподарських машин і знарядь». ЖАК, 2018. С. 167-170.

6. Сорокін С.П., Шкрегаль О.М., Блезнюк О.В., Каденко В.С. Діагностування ЦПГ за струмом, що споживає стартер при прокручуванні двигуна. Матеріали міжнародної науково-практичної конференції «Експлуатаційна та сервісна інженерія». Харків: ХНТУСГ, 2020. C. 121-125. 